\title{
MODERNIDAD Y EXPERIMENTALISMO (El caso de Ramón del Valle-Inclán)
}

\author{
Anthony N. Zahareas \\ University of Minnessota
}

Me ocupo de aproximaciones históricas a la "modernidad" y, en particular, de su aplicación a las contribuciones "modernas" de Valle-Inclán (1886-1936). La modernidad es ya en sí un tema de historia complejo; los códigos modernistas se han propagado de tal suerte que cualquier comunicación engendrada sobre la modernidad tiene múltiples sentidos-la mayoría de las veces contradictorios. En cuanto a las participaciones iberoamericanas, poco se ha escrito que no caiga, forzosamente, en discursos apologéticos: se trata de las quejas de los de la "periferia" que se han excluido del "centro". Así que tanto las modernidades iberoamericanas como los experimentos de Valle-Inclán, dos de los capítulos de la modernidad, no son temas de historia menos complejos. Dar cuenta de la obra de casi cuarenta años de un escritor "moderno", como por ejemplo Ramón del Valle-Inclán, sin examinar los factores históricos de la modernidad que determinan el experimentalismo de sus géneros literarios, ha sido absolutamente inadecuado. He seleccionado, por tanto, los temas centrales de "tradición y ruptura", o de "innovación" y he reexaminado varios aspectos de los experimentos modernos de Valle-Inclán a la luz de esos temas. Esto supone que las ideas y valores por medio de los cuales nos enfrentamos a la llamada "modernidad" de las primeras décadas de XX, están accesibles en la literatura de Valle-Inclán.

\section{La cuestión de la "modernidad"}

Se ha rechazado la creencia de que la llamada modernidad ha de formar una totalidad unificada. Debido a que, respecto a la modernidad, los historiadores de la cultura se han contradicho de modo flagrante, las definiciones resultan casi siempre incompletas o indeterminadas. En el nivel teórico, por ejemplo, se han discutido los fundamentos socioculturales de la modernidad que, al oponerse a innovaciones, irónicamente, acaban por provocarles. Parecidas discusiones tocan una serie de problemas palpitantes como el papel del artista en a la sociedad, la problematización y la autoreflexión en el arte y la literatura, la relación dialéctica entre presente y pasado o el choque entre antiguos y modernos, la función de experimentos; el significado de novedad e independencia, el concepto de cambio y evolución. En el nivel historiográfico, en cambio, se han propuesto varios orígenes (desde el "renacimiento " del s.XIII, al XVIII, siglo de 
las "luces" e incluso, el Romanticismo, hasta la segunda mitad del XX); mientras que a la vez siguen acumulándose los nombres de figuras, movimientos y obras (Goethe, Poe, Baudelaire, Nietzsche, "dada", futuristas, Picasso, surrealismo, Pound, etc.). Por eso se ha argumentado que es inútil intentar captar las tendencias o constantes "elusivas" de la modernidad cultural; lejos de constituir un todo redondo y coherente, la cuestión misma de la modernidad revela unos conflictos y contradicciones de significados.

No obstante, lo que durante años se ha dado por supuesto en las historias de la cultura es que quizá pocos movimientos han producido cambios tan radicales en las culturas occidentales como el movimiento artístico conocido como modernidad (Modernity/Modernism). Las innovaciones asociadas con la modernidad se han proyectado a través de varias artes. De hecho, se han cambiado radicalmente varias formas tradicionales en boga y también las funciones relacionales del arte en la sociedad. Por eso la modernidad, con todas sus variantes, fue algo más que sólo un estilo artístico: se trata quizá de un movimiento intelectual y social que causó un impacto considerable sobre la filosofía, religión, historiografía, ciencia y teorías sociales. Hablar de modernidad equivale a indagar en historias sociales de la cultura. Los efectos causados fueron de tanta repercusión que varios intelectuales del comienzo de siglo creían que había llegado ya una revolución cultural global. De hecho han seguido tan vigentes los efectos de estos movimientos que hoy día nos referimos a nosotros como recién venidos a estos cambios, es decir, como "post-modernos".

Importa recordar, por tanto, que 1890-1930 ha sido uno de los periodos más extraordinarios de la cultura no sólo europea y angloamericana sino también hispánica. Algunos de los mayores pintores, escultores, poetas, teólogos, novelistas, dramaturgos y cinematógrafos... trabajan durante estas décadas. Y he aquí el hecho de que brotan no pocas dificultades que plantea el "problema de modernidad": porque aunque la labor de todos los artistas es variable y diversa, puede decirse que es una labor-una producción de "renovación"-llevada a cabo sólo paralelamente y de acuerdo con la modernidad. Naturalmente, no todos los frutos de esta labor son iguales: no responde siempre a la misma intencionalidad ni la calidad de las obras es necesariamente equiparable. Pero se supone que tiene un aire de familia: tratan de ilustrar, cada cual a su manera, la necesidad de liberarse de los cánones de una tradición considerada anacrónica y opresiva. Por tanto debemos, asimismo, ser conscientes de todas las correspondencias entre el movimiento modernista y sus participantes: fechas, métodos, técnicas, manifiestos, objetivos, diversas manifestaciones, los cambios sociales de modernización y la crisis moderna como telón de fondo. En su doble contenido histórico, "modernidad" designa a la vez la historia social de unas radicales innovaciones artísticas y las innovaciones mismas de esta historia. El conocimiento se ha confundido, así, con las materias.

Todas estas confusiones, por tanto, deben recordarnos que sólo por abstracción se habla de la "modernidad" como categoría igualmente definible en relación con los artistas de cualquier época y país; en realidad, no hay modernidad en general, como tampoco hay "modernistas", "modernos" o época y país; en realidad, no hay modernidad en general, como tampoco hay "modernistas", "modernos" o época moderna en general. Sacadas de su propio contexto de validez histórica, esta clase de teorías o etiquetas universalizadas puede velarnos la realidad histórica antes que ayudar a explicarla. Máxime cuando se nos han impuesto abstracciones de "modernidad" cuya particularidad anlgo-europea difiere demasiado de las de España 
y Latinoamérica. No puede fácilmente afirmarse que la modernidad de un París y otros centros sea igual que la de Madrid y la de otras capitales latinoamericanas.

En vista de las dificultades historiográficas, es necesario acentuar la obvia diferencia entre las discusiones teóricas y generales de la modernidad y las específicas de las obras concretas. La modernidad en general se refiere conceptualmente a la naturaleza y función del arte moderno sin la necesidad de tratar con la especificidad de los modos disponibles en la práctica de varios lugares. La función histórica de la modernidad en las obras de Valle-Inclán, por el contrario, tiene que referirse concretamente, entre otras cosas, a fechas, épocas, contextos sociales, formas genéricas, estilos, modos de producción y diversas recepciones. Una opción es necesariamente creada entre la modernidad en general y las versiones hispánicas de esa modernidad. Ahora bien, una discusión de la modernidad en términos de una figura específica, como ValleInclán, tiene que ser concreta y, paradójicamente, tal concreta ilustración puede conducir a una teoría más viable y a una historia más inclusiva de la modernidad.

\section{La "modernización" de la tragedia}

Vale aquí ilustrar algunos aspectos claves de la modernidad, a modo de in media res, con un ejemplo modélico que desde hace años se ha destacado repetidamente por representar el experimentalismo literario de Valle-Inclán.

MAX. ¡Don Latino de Hispalis, grotesco

personaje, te inmortalizaré en una novela!

DON LATINO. Una tragedia Max.

MAX. La tragedia nuestra no es tragedia.

DON LATINO. ¡Pues algo será!

MAX. El Esperpento.

Los lectores de la ficción de Luces de Bohemia (1920-1924) escuchan a un viejo "bohemio" que, poco antes de morirse, propone modernizar la tragedia tradicional, "esperpentizándola". Remata su cambio radicalmente moderno con la macabra perogrullada de que "los muertos no hablan". Se trata de poner al día el género tradicional de la tragedia, innovándolo: las llamadas tragedias de su cínico compinche absurdo, don Latino, se han de exponer como las grotesquerías de los españoles ya venidos a menos. El objetivo de representar la tragedia tradicional, a guisa de farsa grotesca, era el de lograr a la vez una ruptura con el pasado y una moderna perspectiva hacia lo tradicional. Valle-Inclán hizo de un bohemio frustrado un teórico de arte con la idea de que la representación tradicional del sentido trágico ya no puede mover al público moderno. De hecho, la pretensión de don Latino es tan burlescamente anacrónica como para parecerse a la mejor de las farsas grotescas. Resulta que en el esperpento, metafóricamente, el héroe clásico ha dado un paseo en el callejón de Gatos para mirarse, divertidamente, en un espejo cóncavo.

Los principales conceptos de modernidad se han visto en el ejemplo modélico del esperpento, porque el experimentalismo literario de Valle-Inclán ha de constituir una base sobre la 
cual se puede estudiar con eficacia histórico-cultural todo el edificio cultural de la modernidad. El esperpento de Luces obligó a los lectores a distinguir entre la tragedia moderna como verdadera desviación del canon tradicional y esa misma tragedia como "deformación grotesca de la civilización europea". Por eso la moderna manera esperpéntica de representar el mundo, estéticamente, según los cánones de la tragedia tradicional, articulada significadamente por un "clásico" poeta ciego en el umbral de la muerte, ha sido justamente considerada como un modelo cultural de la transformación progresiva desde una tradición canónica a una modernidad flexible. La afición del esperpento "a lo moderno" se opone deliberadamente "a lo anterior" de la tragedia canónica. Lo que se destaca en la modernidad del esperpento es producir el efecto de shock entre lo acostumbrado de la tradición y el cambio radical de lo moderno.

Valle-Inclán consideró el "cambio" literario del esperpento como "nuevo género" en el cual predomina la manera de "demiurgo". El truco literario de un esperpento (el de Max Estrella) dentro de otro en Luces (el de Valle-Inclán), otorga a la propia construcción del nuevo género algo "moderno": se redobla como autorreflexión el nuevo proceso de formación tragifársica. Se trata de forjar un arte moderno dentro del arte tradicional. La sustitución de ver la vida como tragedia por el moderno esperpento señala una ruptura radical, un rechazo moderno de lo ya gastado y el comienzo de una nueva manera de representar "moderadamente" la realidad histórica sin muchos precedentes hasta entonces. De hecho, se ha producido un nuevo género literario consciente de sí mismo con respecto tanto a su modernidad como a los cambios técnicos de comunicación: modernísticamente hablando, el arte literario, como cualquier forma de producción, depende de ciertas técnicas de representar cosas. Las adapta, sin embargo, "para evolucionarlas. Los cambios hacen de la obra, conscientemente" puro arte por arte, un artefacto; y a la vez, replantean una nueva serie de relaciones sociales entre el artista y su público.

En Luces se opone al género clásico de tragedia tradicional el género moderno de la mojiganga moderna. La modernidad aquí implica que la adaptación esperpéntica de la tragedia tradicional plantea una totalidad de cambios innovadores. Supone una clara escisión entre lo dado y lo cambiable. Dentro del esperpento Luces, el nuevo género es deliberadamente comparable a la proverbial hoja de papel: la tragedia tradicional es el anverso y el esperpento moderno el reverso; no puede rasgarse una carta sin rasgar al mismo tiempo la otra. En todos los niveles de la obra, se proyecta una mutua depencia de los dos opuestos: Valle-Inclán eligió dramatizar (algunos modernos dirían "cinematografiar") la bohemia española no directamente como "una deformación grotesca de la civilización europea" sino, al contrario, como un esperpento en tanto desviación moderna de la tragedia tradicional. Lo moderno, al serlo, es negación de lo tradicional: el esperpento no existe por sí mismo debido a que se plantea a la vez lo que es tragedia, es decir, aquello que el nuevo modo esperpéntico subvierte, niega y substituye o reemplaza.

Así que en el primer esperpento, Valle-Inclán ha revolucionado en sus raíces el aparato mimético de la tragedia clásica. Más allá de forjar una visión moderna a través de los medios de tragedia existentes, logró revolucionar los medios mismos. En esto, parte de los temas predilectos de la modernidad (alienación de la vida urbana, proceso de marginación, riqueza de lenguaje contra la vulgaridad diaria) para llevarlos a un fin político-artístico: "el sentido trágico en la vida española sólo puede darse con una estética sistemáticamente deformada". La literatura esperpéntica de Valle-Inclán se centra, modernamente, sobre la imposibilidad de disociar la función "poética" de la función "crítica". Se trata de alterar el ordenamiento expresivo, configurar 
nuevamente los lugares tradicionales de la "escritura", poner fin a las seguridades del maridaje entre el hombre y su palabra. La redefinción innovadora del portavoz valleinclaneano, Max Estrella, plantea una disyuntiva que es típica de todos los procesos artísticos de la modernidad: no puede existir modernización, es decir, transformación de una forma tradicional, sin un conocimiento sólido de la tradición que se quiere modernizar. Solo con una clara conciencia de cómo han funcionado dentro de la tradición los medios de comunicación es posible cambiarlos y ponerlos al día. Es lo que ha realizado Valle-Inclán al esperpentizar la tragedia en Luces de Bohemia.

\section{Modernidad y Valle-Inclán}

Quizá ningún escritor ha cultivado de manera innovadora tantos géneros literarios. Durante las décadas 1890-1930 apenas pasaba un año sin que apareciera otro esfuerzo de modernizar las formas literarias tradicionales. Y como otros modernistas, Valle-Inclán desafiaba los esquemas mentales del público nutridos por la tradición. De ahí la paradoja: por un lado, es hoy el autor más privilegiado de las letras españolas y, de hecho, ocupa una posición destacada para entender los factores problemáticos de la modernidad; por otro, respecto al panorama global de la modernidad, Valle-Inclán sigue desconocido. No ha compartido nunca un lugar con Apolinaire, Picasso, Elliot, Joyce, Kafka, Brecht. Es un hecho: Valle-Inclán, protagonista de tantos estudios y simposios, es el "gran excluido" del canon modernista. Esta contradicción entre un escritor del todo "moderno" y su exclusión casi total del canon angloeuropeo, contiene los problemas historiográficos de los "periféricos" que se han de afrontar. Según la realidad histórica de la modernidad tal y como se ha articulado, no hemos podido hablar "coherente" y a la vez "comparativamente" acerca de Valle-Inclán.

La obra de Valle-Inclán es inmensa y a la vez diversa: incluye sonatas decadentes, ficciones históricas sobre las guerras carlistas, tragedias rurales a guisa de "Comedias bárbaras",cuentos de leyendas, toda especie de obras dramáticas (farsa, tragicomedias, tablados, poesías de ferias y exotismos; esperpentos y novelas históricas esperpetizantes). En todos estos géneros el proceso demiúrgico corresponde hondamente al arte literario moderno: lenguaje sintético, efectos plásticos, fusión de géneros, fronteras entre historias y ficciones, subversión de ideologías dominantes, arte de "pastiche-mosaico-montaje", experimentos formales, trasfondos bohemios y anarquistas, vanguardismo y símbolos de varios ocultismos. Tenía en cuenta (como más tarde Brecht) la importancia de atacar los esquemas de los lectores, obligándolos a una toma de conciencia y a la capacidad de conservar su lucidez de juicio. De ahí la idea articulada del distanciamiento de ver el mundo enajenadamente, "desde el aire": no se trata de dejarse emocionar, movido, por una historia trágica del dolor, sino de poder alejarse y guardar la distancia que permita, más allá de emocionarse, razonar y juzgar.

El caso esperpéntico de modernizar la tragedia no es un ejemplo aislado; desde antes de Luces de Bohemia, las obras de Valle-Inclán se inscribían en la corriente del arte moderno como reacción contra la época en que todavía el peso de la tradición es lo que contaba sobre todo. La llamada modernidad se ha convertido en doctrina artística de tendencias renovadoras, todo como reacción contra lo tradicional. En vez de imitar el mundo, inventarlo; pasar de la notoria 
"ilusión de la realidad" al concepto moderno, al revés, de "la realidad de la ilusión". Apartarse de la lengua común a todos al "estilo por el estilo", elegido y cultivado por el escritor. De ahí el elitismo al lado del populismo en Valle-Inclán. La modernidad designa, entre otras cosas, ciertos cambios radicales en la cultura. El objetivo era sacar al "arte" del ghetto en que la había recluido la llamada "tradición" dominante. Todas estas implicaciones se manifiestan en Valle-Inclán: 1) desconfianza del orden establecido de un mundo estancado, falto de novedad; 2) deseos de elaborar un arte que respondiera al día, que sea cambiable e innovador; 3) sabotaje de los modos tradicionales de hacer literatura; 4) rechazo de las mismas concepciones tradicionales del arte; 5) inquietud con respecto al lenguaje y la escritura; 6) escepticismo ante las certidumbres religiosas y ético-morales; 7) gravitación hacia la vida artística o legendaria de París; 8) afán de adelantarse a su época y a modo de precursor, cambiar lo viejo por lo nuevo; 9) pretensión de extender una insurrección artística contra el canon tradicional a todos los campos de la cultura; y , a veces, 10) la aspiración por medio del arte a la transformación total de la vida.

Siguen los debates en torno a la modernidad; incluso se ha dudado o negado el fenómeno. La modernidad, no obstante, ha sido indiscutible en cuanto a su existencia histórica. Recientemente, Carlos Blanco ha tocado el problema de la hegemonía modernista desde del ángulo histórico de la periferias como entre éstas, España y Latinoamérica. Ha destacado la hegemonía de la estética de la "autonomía" en el seno de la cultura, hegemonía que se ha perpetuado a costa de los exluidos hasta hoy día. La "autonomía estética" se ve hoy día a través de una exposición histórica de su emergencia durante el largo proceso de "modernización". Tras la liberación de las disciplinas del yugo tradicional de la teología y de la tradición, hubo dificultades debido a que las nuevas obras eran consideradas como subversivas, descreídas e incluso blasfemas. Era difícil aceptar que la literatura ya tuviera por objeto impuesto la propia literatura.

El siglo XX está sacudido en sus comienzos por la crisis cultural y los nuevos movimientos que impulsaron con renovado virgor los problemas modernos de la cultura tradicional. Irónicamente, cuanto más se ha dicho en general acerca de la modernidad, menos se ha conseguido hablar sobre casos concretos-he aquí los ejemplos destacados de Valle-Inclán y el mundo hispano. Valle-Inclán aspiró a practicar la modernidad como las ideas, valores y sentimientos por medio de los cuales los pueblos se han enfrentado a sus sociedades en las primeras décadas del XX. Resulta que los valores de la modernidad, desde hace mucho, están a la disposición de los historiadores literarios en los géneros cultivados por Valle-Inclán.

Gracias a Valle-Inclán, no obstante, es posible revisar los lugares comunes de la modernidad con más precisión, precursor, renovador, vanguardismo, paradoja y ambigüedad, subversión, lo fragmentario, enajenación, cambios de técnicas, secularización de cultura, rebelión, marginalismo, etc. Todo se hizo contra la burguesía pero desde dentro de ella: vivir la vida en nombre del arte. El tiempo, los siempre "fin de siglo" y "belle epoque". La topografía (Seine, Paris, viejo Madrid, bares, cabarets, 27.000 cafés. burdeles, Bohemias, bohemios) sale como fotos instantáneas. En medio de todos estos lugares se destaca el cambio: el afán de autonomizar el arte respecto a la vida cotidiana; organizar la vida desde lo artístico ("todo el mundo es arte"). Se trata de dar nueva forma no sólo al arte sino, por medio del arte, a todas las cosas, incluso: cómo se frecuentaban los caminos; cómo se pintaba la gente; cómo se comía o se vestía; cómo se reaccionaba a la familia, a la guerra, etc. La base de la modernidad ha sido cómo el arte, sin dejar de ser sólo arte, apela al sentido de la realidad del público. Lo cual replanteó el 
complejo problema de la "comunicación": comprender la "irrealidad" de lo que ocurre en "ficción” y a la vez pretender como si se tratara, en plena ficción, de algo "real".

La contribución de Blanco consiste en enfocar todo el problema modernista de acuerdo con las condiciones históricas de centro y periferia. Asimismo es consciente de las condiciones históricas de España y Latinoamérica: la periferia frente al centro. Valle-Inclán da carta de validez a los argumentos históricos de Blanco: la cultura hegemónica que ha definido la modernidad ha podido al mismo tiempo apropiarse y excluir lo que le conviene de la periferia. Podemos cuestionar todo esto pero, históricamente hablando, es así. ¿Puede interesar Valle-Inclán fuera del mundo iberoamericano? Pues bien, con respecto a la modernidad, Valle-Inclán era escritor innovador desde las Sonatas en adelante hasta los esperpentos, Tirano Banderas y El ruedo ibérico entre otros. No aceptó acríticamente los modos existentes de producción artística sino que desarrolló y revolucionó la narración en "primera persona", el "fragmentario" drama shespiriano, el realismo anacrónico de la tragedia, la farsa, la novela histórica, el tablado, etc. Haciéndolo con eficacia (sobre todo respecto al "montaje" y "simultaneísmo" de tiempos y lugares) logró crear nuevas relaciones sociales entre el escritor y el público. Sobre todo, se destaca el afán moderno de desarrollar nuevos medios de comunicación.

Finalmente, seducido por lo grotesco de la tradición luso-hispánica y, sobre todo, por las técnicas modernas y modernistas del fragmentarismo, montaje y simultaneísmo (entre otros experimentos) inventa un nuevo género, el esperpento, y lo convierte en una nueva manera de narrar histórica y ficcionalmente los episodios nacionales de España e Hispanoamérica. El arte moderno de este nuevo género es, como se debe, "puro artefacto", demiúrgicamente generado, y, por tanto, resumen y cristalización, de toda su literatura (ya que todo producto de Valle-Inclán es "a lo moderno" pura fabricación). Esta pureza, no obstante, tiene la función histórica de representar a los españoles como intérpretes de su historia que son inferiores, como peleles, ante las exigencias de sus papeles. En esto, es el excluido Valle-Inclán quien nos ayuda a aclarar una de las paradojas con respecto a toda la modernidad: el "destradicionalismo" del artista lo es, no sólo como ciudadano sino como creador demiúrgico, se trata de "enajenarse" desde la estética y no desde la política o la moral.

Total: volviendo al ejemplo modélico de Luces de Bohemia, la modernidad de Valle-Inclán se manifiesta en la dependencia mútua de dos contrarios: el predominio del "proceso" artístico sobre la lección del arte y la función del arte como "mercancía". Como ilustración analógica del arte moderno, visualicemos el ya notorio cuadro Demoiselles d' Avignon de Picasso que en 1906 hizo historia por los objetos geométricamente captados. ¿Cómo llegó a ser pintado? Tras diversas especulaciones casi exóticas, yace la realidad: nada menos que 809 estudios preliminares (esbozos y planes) uno tras otro, indicando todo un "proceso" de cómo se hace una pintura. Se trata de los "quehaceres" de la producción artística. Para la conciencia moderna, el "proceso" de la pintura en su misma evolución es tan importante como la pintura en sí. El proceso está inscrito dentro de la obra, dándole una "autorreflexión". Uno de los objetivos de la modernidad es secularizar el producto, quitándole la llamada "única" finalidad. Este debate aparece con mucha sutileza en Luces. Nadie menos que el “ ficticio” Bradomín (ya viejo de 90 años y legendario carlista) le está tomando el pelo al "histórico" Rubén Darío. Después de la muerte de Max, en el cementerio, meditabundo, Darío escribe alguna palabra en el sobre de una carta, unos escasos renglones. Se niega a leerlos hasta... depurarlos. Los considera todavía un "monstruo". La reacción del Marqués es reveladora: 
Querido Rubén, los versos deberían publicarse con todo su proceso, desde lo que usted llama monstruo hasta la manera definitiva.Tendrían entonces el valor como las pruebas de aguafuerte. ¿Pero usted no quiere leérmelos? (Nuestro énfasis).

El proceso de grabado al ácido nítrico (aguafuerte) tiene que ver con pruebas lo cual hace que el grabado lleve dentro de sí el proceso mismo de su creación. Es una metáfora tanto brillante como precisa. Aquí Valle-Inclán coloca el quid del debate modernista en medio de su nuevo género del esperpento: según el argumento de Darío, el poema ha de formar una totalidad unificada, como un organismo natural; "depuración" implica algo orgánico. Es precisamente esta idea tradicional que escandalosamente rechaza el astuto Bradomín: es en sus significativos procesos del texto final, en sus vacíos, incluso las "monstruosidades" y cosas incompletas donde la presencia del proceso artístico puede sentirse de manera más positiva. El texto moderno puede contener estos procesos de su creación aunque, por eso, resulte "fragmentado", "incompleto" y "descentralizado". La conciencia de la modernidad está inscrita en el diálogo sobre el proceso de hacer arte de acuerdo con las normas del arte. Son notorias las reelaboraciones de Valle-Inclán de sus propios textos.

No es accidental que el mismo Bradomín, a raíz de su metáfora moderna sobre el proceso de arte como "aguafuerte", exponga la cuestión moderna del arte como mercancía. Recuérdese que los lectores de Luces, en 1920-1924, supieron de un viejo aristócrata "pecador", arruinado económicamente que, en el umbral de la muerte, se convirtió en "escritor" para narrar, en primera persona, las memorias de su vida amorosa. Pero antes, ya en 1903-04, se habían publicado como "memorias" amables del Marqués de Bradomín, un don Juan feo, católico y sentimental, supuestamente escritas por él mismo como si fueran una autobiografía de cuatro artificiosas "sonatas". Ahora bien, un personaje ficticio sale como si fuera histórico en carne y hueso de las páginas de unas artificiosas sonatas para venderlas, con la ayuda de la figura histórica de Darío (cuyos poemas publicados incluyen un soneto otoñal sobre Bradomín) quien, muy conocido, deja el verdadero mundo social de la bohemia para entrar como personaje ficticio en un artificioso esperpento cuyo personaje artificiosamente híbrido, Estrella Sawa, era amigo de los dos. Son las impresionantes pirotecnias artificiosas de ficción; pura brillantez y juego dentro de las consecuencias estéticas de la doble perspectiva planteada por Valle-Inclán. En el caso de las Sonatas y Luces, se empeña en plantear el factor socio-económico del arte literario; resulta que la literatura, según el viejo Bradomín, puede ser un artefacto, un producto de la conciencia personal, una visión del mundo (tocada sarcásticamente al señalar la diferencia entre Shakespeare y los hermanos Quintero)...; pero es también una industria donde los libros son asimismo mercancías producidas por los editores y vendidas con beneficio en el mercado. Es decir, arte, sí, pero mediatizado con respecto a la economía. El histórico Rubén Darío aquí ficcionalizado, ha de ayudarle al ficticio viejo Bradomín, aquí historizado, para que el puro arte de unas sonatas autobiográficas sea contratado por una editorial (donde roban a los artistas) para venderse, ganando dinero para el escritor.

Así es que durante el entierro del teórico esperpento, Max Estrella se plantea el doble caso del arte moderno; por un lado, cómo se hace el arte (incluso el esperpento) en que se destaca el proceso de creación; por otro, el proceso del arte como mercancía en que se destacan las bases económicas de la producción artística. Sorprende la lucidez de Valle-Inclán al tocar todas 
estas cuestiones palpitantes de la modernidad. Era en su tiempo el autor "profesional" por excelencia: sabía que el arte literario, por independientes que fueran sus modernos géneros literarios, era también parte de una industria, el único medio que tenía para ganarse la vida. Lo cual quiere decir que la literatura de Valle-Inclán dependía de ciertas técnicas de producción artística, modos de plasticidad, de espectáculo, musicalidad, montaje, tablados populares, procesos fílmicos, siluetas, acotaciones gráficas, etc. Valle-Inclán, como ya hemos dicho, se consideraba a sí mismo artista auténticamente "revolucionario"; no por lanzar mensajes, ideas y valores sino por su capacidad de cambiar a lo moderno los medios artísticos a su disposición.

\section{Experimentalismo y Modernidad en Valle-Inclán}

La obra de Valle-Inclán consta de dos elementos básicos: primero, el afán de transformar modernamente los modos tradicionales de hacer literatura y desarrollar nuevos medios de comunicar mensajes, y, luego, la producción densa de una serie de géneros literarios en torno a ese afán de experimentar. Así que la totalidad de su literatura está segmentada en obras de géneros distintos, cada una de las cuales representa un experimento moderno respecto a los medios artísticos heredados de la tradición. Estos géneros particulares se han cultivado sistemáticamente a través de casi cuatro décadas, lo cual indica una serie de transformaciones sucesivas, particularmente las que se han sometido a modernos experimentos literarios. No se trata de una simple acumulación de distintos experimentos y de ahí obras genéricas; se trata más bien de un proceso experimental a lo moderno, históricamente bien coherente: en cada nuevo género literario se evidencia el afán al experimento de los medios, la riqueza de lenguaje, cierto vanguardismo, fusión de lo elitista con lo popular y profundidad de visión. El aspecto genérico varía de una obra a otra pero la modernidad se identifica bien por el logrado experimento en torno a las formas literarias a su disposición. No creo que se haya estudiado sistemáticamente la modernidad de Valle-Inclán de acuerdo con el cultivo de géneros literarios.

Por ejemplo, ¿qué es Tirano Banderas? ¿Y a qué género pertenece? No es nada tradicional. El objetivo parece ser demostrar que el locus de la novela, Santa Fe de Tierra Firme, es, realmente, "ningún lugar" y, como tal, pura ficción; digamos, la versión grotesca-esperpéntica de la "utopía" tradicional. Tampoco los temas y mensajes pretenden ser originales: es la vida sufrida bajo dictadores, como la muerte, la superstición, la naturaleza, la violencia, el fatalismo, las ciudades, la decadencia, la hipocresía. Valle-Inclán "metamorfosea" toda esta tradición con la libertad de un "pluri-lingüista" demiúrgico tanto que ni se digna aparecer en la novela. El resultado es un "simultaneísmo" lírico cinematográfico. Sí, logra estigmatizar los engranajes diabólicos de las dictaduras militares pero todo a base de la técnica artificiosa y muy moderna del montaje: asocia varias cosas opuestas y por tanto fragmentadas para provocar por medio de un shock una idea radical en el público. Se trata de una producción literaria de un género literario en una época de tecnología-fotos, periódicos, cine mudo, discos, la fotografía, modas; son medios que modificaban profundamente los modos de percepción tradicionales.

Se trata de los medios modernos de producir géneros literarios. El caso de Tirano Banderas vale como modelo para toda la producción literaria de Valle-Inclán. La visión grotesca de los fatalismos políticos del mundo latinoamericano, como cualquier realidad social, sólo es in- 
teligible en Tirano Banderas a través de su estructura narrativa, modernamente segmentada a modo de marcos instantáneos. El fragmentarismo modernista es un "todo" en el que los elementos políticos no se yuxtaponen sino que, a modo de montaje, se encuentran distribuidos en la lectura según una organización descentrada del conjunto. Es esta organización fragmentaria a modo del cine mudo la que determina la función grotesca que desempeña cada elemento, siluetas, momias, atrocidades, supersticiones, gachupinismo, utopías, politiqueo, etc. El resultado es convertir la ambigüedad geográfica y temporal de la narración en un sincretismo cultural del todo artificial pero a la vez lleno de referencias históricas. El nuevo género experimental de ValleInclán está en el corazón de la problemática modernista: por un lado, en el mismo acto de funcionar bajo condiciones históricas, el nuevo género literario sobre tiranías muestra su completa ficcionalidad; y, por otro, esta misma ficcionalidad de Tirano Banderas no puede evitar la función histórica de su lectura. Se trata de un fragmentarismo bien hilvanado.

"Género" se refiere a tipos y especies, maneras y clases; ciertas obras literarias se clasifican según ciertos caracteres semejantes, con subdivisiones, drama, tragedia, comedia, tragicomedia. "Género", por tanto, es de un doble contenido, designa a la vez la representación de ciertas materias y las materias de esta representación. Entendemos el género de "historia", por ejemplo, como el conjunto de hechos pasados referentes a un grupo determinado. De hecho, cualquier género literario invoca automáticamente una tradición; y depende de ella para su identidad. Valle-Inclán adaptó muchos géneros, sacados de la tradición, estudió sus técnicas particulares de producción (ciertos modos de describir paisajes, de dialogar, de retratar, de representar dramáticamente) y sobre todo las relaciones proyectadas entre el escritor y el público. Casi siempre metió mano, experimentó, integró innovaciones, logró fusiones y acabó revolucionando el género adaptado, cambiando radicalmente las relaciones sociales entre el autor y el público receptor. Como su contemporáneo Picasso, Valle-Inclán representa "una vertiente clave" de la modernidad.

No se ha hecho un estudio sistemático acerca de las estructuras internas en los diversos géneros de Valle-Inclán desde 1890 hasta 1930. Para hacerlo hay que referirse a las diversas funciones conectadas con la composición, producción, transmisión y recepción de diversos géneros como historias, memorias, tragicomedias, farsas, novelas históricas entre otros. Es decir, vale fijarse en la posición del texto dentro de los modos existentes de escritura y lectura. Se trata de inmensos problemas historiográficos desde el ángulo escueto de los mejores representantes, como Valle-Inclán; por ejemplo, entre 1889-1900, esbozos, cuentos, artículos, leyendas, drama, versos, traducciones; entre 1900-1905, modernismos, memorias como sonatas, estéticas, novelas cortas, adaptación de comedia, reelaboraciones; entre 1906-1910, conversaciones teatrales, diálogos, teatro épico-trágico, comedias bárbaras, novelas históricas, poemas a lo gallego, novela, farsa para niños, antologías; entre 1911-1920, tragedia pastoril, commedia dell'arte, mística, gnosticismo, estética, credo, versos carnavalescos, farsa en verso, tragicomedia, esperpento; entre 1921-1930, trilogías, poemas, tablados, cinenovela, comentarios, ruedos.

Es sólo una vista de pájaro. Todo se ha hecho conscientemente moderno. Es quizá la variedad de géneros más diversa de la historia de la literatura. De hecho, hace falta un análisis histórico de la modernidad de Valle-Inclán desde los primeros experimentos y agrupaciones hasta los esperpentos, tablados y ruedos, haciendo un esquema de las modernas formas literarias en que sus géneros adaptados cambiaban tal como cambiaban las vicisitudes de la modernidad en 
las que el arte genérico de Valle-Inclán hundía sus raíces experimentales. Queda por hacerse. Lo que podemos ofrecer, sin embargo, son algunos ejemplos destacados de los géneros para destacar brevemente la modernidad de Valle-Inclán a la luz de ellos. Cada género marca una ruptura en ciertas convenciones narrativas, dramáticas o poéticas, ruptura que encarna distintas maneras de percibir y ser sensible a las realidades históricas. Son soluciones estéticas para problemas históricos.

\section{Los géneros literarios de Valle-Inclán}

Al ser adaptados por Valle-Inclán para la época moderna, las características de varios géneros se repiten para transformarse. Cada género literario cultivado por Valle-Inclán comienza siendo tradicional porque se ha "institucionalizado", es decir, se da por "heredado" y por tanto sentada la acumulación modélica de ciertos elementos y principios de comunicación. Los factores genéricos de las Sonatas, por ejemplo, en los primeros años del siglo, dependían de ciertas técnicas de transmisión (primera persona, episodismo diacrónico, individuo y sociedad) modos literarios en potencia cambiables. Ahora bien, existen "distancias" entre un género adaptado por Valle-Inclán y las posibilidades de una representación moderna y por tanto variable: al adaptar desde 1920 en adelante el género de tragedia clásica a las condiciones de bohemios, cornudos o golfos, se plantean claras distancias entre las reglas genéricas y muchas posibilidades de variación. El esperpento, así, ha revolucionado las fuerzas modélico-simbólicas del género clásico de la tragedia. Así que cualquier estudio de los nuevos géneros de Valle-Inclán ha de ser estudio de una "ruptura"; en el caso de los esperpentos, la ruptura entre la tragedia institucionalizada y su modernización.

Comencemos con el caso de las Sonatas. Se han caracterizado por su acusado sensualismo, la búsqueda consciente de un estilo lingüísticamente musical, muy refinado ("fue Satanás") , la exaltación del amor como exaltación erótica y la obsesión por la muerte. El Bradomín, malicioso y estéticamente "feo, católico, sentimental", como seductor y esteta del amor, era también esteta de la escritura. Así son las reglas del juego narrativo a través de las cuatro sonatas músico-narradas; como con toda autobiografía literaria, incluso las picarescas, confesiones, memorias o diarios, el autor, Valle-Inclán, decidió que el protagonista mismo narrase por escrito sus memorias. ¿Cuál es la "posición" (o “ángulo") desde la que Bradomín (que no Valle-Inclán) aborda cada uno de los episodios pretéritos de sus amores vividos por él? Narrativamente, los pasados amorosos de Bradomín, por nostálgicos, son ya unos pasados no renovables: se puede confundir, así, el pasado real de Bradomín con el pasado mnemónico que le ha sido transmitido al lector. El pasado se transforma, conscientemente, en una "construcción" hecha por el viejo que lo ha narrado e interpreta por el medio musical de tonos sonatines los episodios de amores de antaño. La problemática del género tradicional es moderna: ¿de qué manera puede razonar el viejo Bradomín sobre un pasado en el que ya no puede intervenir activamente? Sólo en su ficción, estructurada a sabiendas como cuatro sonatas. Así que el género autobiográfico, al adaptarlo Valle-Inclán, ha incorporado dentro de sí, su modo de estructurarse, un proceso continuo de interacción entre el narrador, Bradomín, y los hechos amorosos de sus memorias; históricamente, un diálogo sin fin entre el presente del viejo y el pasado del joven. 
El caso de las Comedias Bárbaras (1905-1921) y la imponente figura del protagonista, Montenegro, personaje "típico" o "representativo", encarna las fuerzas históricas (el aristócrata cuya casa y familia han venido a menos) sin que por eso deje de estar dramáticamente individualizado. Las Comedias Bárbaras, no obstante, no es un documentario moderno, para la modernidad, el mundo del artefacto (llamémoslo el mundo ficticio) no es idéntico al mundo real o histórico, como por ejemplo la Galicia en que Valle-Inclán vivió. Así que, dada la importancia del factor histórico de estos dramas sobre mayorazgos, hay que considerar al mismo tiempo otro grupo de normas, las que se articulan adentro del texto dramático. Se independiza la ficción del arte dramático al depender de la historia. Lejos de constituir un todo redondo y coherente, revela un conflicto y una contradicción de significados. Así que la modernidad entra en la fícción de Valle-Inclán, en el lenguaje mismo, un lenguaje "hecho", artificial, que codifica un mosaico de referencias o alusiones históricas. Las tendencias modernistas no siempre aparecen claramente, ni se anuncian como tales: más bien están esparcidas de forma clandestina entre los diálogos, acotaciones, valores, argumentos, imágenes y mitos. La modernidad de Valle-Inclán en Romance de Lobos es un conjunto de técnicas literarias que han hecho un texto dramático. Tales técnicas pueden ser más o menos lingüísticas pero proveen un montaje en que se unen dialécticamente el espectáculo teatral con la historia de la decadencia de clases. Este montaje artificial es el marco del cual el protagonista Montenegro entiende y participa en su sociedad arcaico-gallega.

El título Las guerras carlistas para las tres novelas históricas (1907-1909) es revelador por lo que indica, con respecto al proceso historiográfico, cómo se hace la historia, incluso la versión épica de la causa carlista. Sugiere la transformación que empieza a apoderarse de todos los diversos acontecimientos de una guerra civil desde el mismo momento en que ocurren: no puede evitarse una cierta selección, lo cual, además, está determinado por factores políticos, 0 por meros accidentes de interés y atención. Poco a poco la totalidad de los acontecimientos se desmorona y se funden en el pasado; y todo lo que queda de los hechos pasa a la custodia de una caprichosa e imperfecta memoria humana. La imaginación se adueña y los reconstruye mediante otros fragmentos, formando así de los dispares fragmentos una construcción ideal, digamos, a modo de una gesta épica. El esbozo y plan de esta construcción narrativa ya puede haber existido antes de que este material cayera en las manos del narrador que la incorpora a su historia. A esto hay que añadir los efectos acumulativos de la tradición oral. Metafóricamente, un edificio ideal se derrumba, algunos trozos, conglomerados de fragmentos fortuitos y mal clasificados, son transportados a otro lugar y convertidos en la estructura de un modelo mítico, quizá bastante diferente del original histórico. Así también unos hechos se convierten en leyenda y la leyenda en un mito. Los hechos se desconectan: se desprenden de sus raíces en el tiempo y el espacio, y se convierten en una historia narrada, una fábula. Este cuento es moldeado y remoldeado por la misma imaginación, por la pasión y el prejuicio, por una actitud política preconcebida o un instinto estético, por el deleite en lo supersticioso, por un ansia moralizadora, por el placer de recordar y contar un buen cuento... hasta que los hechos acaecidos se convierten en leyenda. Todo este proceso está implícito en las novelas históricas de Valle-Inclán; el sentido épico está inscrito en la historia con las diferencias de la modernidad.

El proceso historiográfico de las Guerras Carlistas se repite pero con mucha diferencia durante la época de los esperpentos. En su doble contenido, El Ruedo Ibérico designa a la vez la narración histórica de unos sucesos de crisis pasadas (de una duración de seis meses) y los su- 
cesos pasados de esta narración histórica. Los lectores han de entender el conjunto de unas trágicas mojigangas pasadas referentes a varias figuras nacionales, pero también han de entender por tal una "historia" o una "novela" sobre dichas mojigangas. Resulta que, desde la perspectiva historiográfica (lo mismo da si en ficción épica o crónica grotesca), puede invertirse dentro del mismo proceso adaptado. El narrador de Valle-Inclán ahora desea influir en cómo el lector español debe leer su pasado de crisis absurda y por tanto no deseada, en una totalidad estructurada y visión grotesca por el medio moderno de trucos ingeniosos y fragmentos aislados. Así que en la deformación grotesca de la crisis nacional historiada por el narrador, el lector, como el receptor de un espectáculo, tiene que afrontar dos estructuras: "una" es histórica, la de la crisis vivida por los españoles y el narrador, la de las absurdas experiencias ya sufridas, incambiables pero recordadas ahora por el narrador; la "otra" es el discurso narrado o escrito de esta crisis sufrida, es decir, el pasado episódico del "ruedo ibérico" como objeto literario del narrador. El narrador de Valle-Inclán, mediante una sucesión causal de grotescos episodios pretéritos, captados en los mismos títulos figurativos, deforma ahora la crisis pasada, metaforizando la historia como si fuera un espectáculo de corrida, es decir, un discurso literario con su retórica, montaje, giros estilísticos, chistes, burlas, eufemismos, imágenes, diálogos, e incluso jerigonza y dialectismos. En fin, se les viene a los españoles su crisis de conciencia histórica ya rehecha igual que en un manual de historia idealizada.

En cuanto al nuevo género del "esperpento", Luces de Bohemia, Valle-Inclán no sólo convierte en espectáculo, a modo de montaje, una tragedia socio-política más, sino también el exitoso encubrimiento grotesco del terrorismo grotesco- -"la ley de fugas". Esperpento aquí indica la aplicación "matemática" de una manera "alienadora" de observar, en ficción, a los españoles de la historia moderna a la luz de sus aspiraciones fantochescas de poseer, a lo tradicional, una existencia trágica. El idealismo heroico de las antiguas figuras trágicas es representado modernamente por un "espectro" de la bohemia "ahora en medio del arroyo, oliendo a aguardiente, y saludando en francés a las proxenetas". Afectando así papeles, ¿pueden unos minúsculos sostener el gran peso del problema de España? "De ahí nace el contraste, la desproporción, lo ridículo". Si "la ceguera es bella y noble en Homero", "en Luces de Bohemia, esa misma ceguera es triste y lamentable porque el héroe no es sino un poeta bohemio". De poco peso. Manifiestamente ridículo, el bohemio soñador no es capaz de trascender con su ilusión trágica el nivel burlesco de su irrealismo. Entre una década (Sonatas, Comedias, Guerras) y otra (Tirano Banderas, Ruedo Ibérico y Martes de Carnaval) el primer esperpento hace puente entre varios géneros y muestra el afán clave de la modernidad: seguir revolucionando los aparatos tradicionales de las comunicaciones literarias.

En el caso de Los cuernos de don Friolera, la dramatización variada del militar deshonrado resulta ser un grotesco perfectamente hilarante sobre un cornudo, al cual los lectores dentro de la ficción, como por ejemplo don Estrafalario, están aún todavía aprendiendo a tomar históricamente en serio. Si existen ambigüedades en el fondo conceptual de Friolera es porque la materia tradicional utilizada como material de este entretenimiento burlesco es, precisamente, la miseria y la desgracia humanas de la tragedia tradicional: Medea, Otelo, Médico, entre otros. Al envolver burlescamente en la percibida deshonra del militar las ideologías sobre las crisis y la decadencia de España, las humorescas escenas teatralizadas ofrecen un marco dentro del cual los españoles comprendían y participaban en su sociedad. Al igual que España, Don Friolera 
buscaba soluciones tradicionales del pundonor para un mundo moderno. Era locura ante los cuernos, es cierto, pero lo era solo por la razón de su implícito anacronismo grotesco. Como metáfora de la incompetencia de España y de su desadaptación, gráficamente simbolizadas por el mal encajado uniforme militar y los monólogos mal ajustados del protagonista, así como por su presuntuoso discurso, la cornología burlesca sirve como análisis sutil de la decadencia militar de España. Ayuda a ubicar la teatralería de las escenas cornológicas en el corazón de la historia moderna de su nación.

\section{Valle-Inclán y la Modernidad}

Y así por el estilo con respecto a la función histórica de los géneros literarios, Rodolfo Cardona y yo ya hemos indicado cómo Valle-Inclán articuló el tema de la modernidad. Lo que se necesita en España es un arte flexible, lleno de posibilidades, en el que tanto el autor como su público, al distanciarse, puedan adquirir la capacidad estética de divertirse ante un espectáculo aún cuando el goce estético ocurra a expensas de los trágicos problemas de España. Así, la dimensión creativa del arte estará enraizada en la capacidad de los autores para considerarse superiores a los personajes creados, quienes, como los muñecos de un tabanco, a pesar de sus pretensiones trágicas, parecen ridículos en sus posturas heroicas, declamaciones trágicas o etiquetas míticas. La mejor manera de modernizar la literatura española es introducir en la literatura tradicional el distanciamiento cómico, el sabor popular y el sentido malicioso de los "géneros" populares de tabancos de muñecos. Así, una forma radical de tratar y representar las realidades históricas en el arte, más allá de una elaboración nueva en los viejos contenidos, es la de revolucionar el aparato de las formas del arte mismo. Valle-Inclán tenía una clarísima idea de lo que hacía al sugerir tales conexiones entre la forma de arte y la historia; la razón por la que algunos modernos juegan con el distanciamiento en su arte es que lo que sucede en la vida social en España es angustiosamente absurdo. España continúa afirmando su grandeza trágica por medio de un tinglado trágico sin que exista una base histórica ni la competencia necesaria para sostenerla. La tragedia moderna no es más que otra etiqueta ideológica. El hecho es que un así llamado papel trágico es tan difícil que, metafóricamente, es superior a los actores españoles llamados a representar la historia de España; cuando los actores gesticulan patéticamente en su persistencia en hacer los papeles trágicos de la tradición, están actuando en vano y, en sus declamaciones patéticas, aparecen como lo que verdaderamente son, muñecos gritones en el espectáculo histórico de la continua y absurda tragedia de España.

Las palabras de Valle-Inclán sobre su arte moderno son maliciosamente históricas en su contenido. Primero, se identifica a sí mismo con Cervantes, Quevedo y Goya y con la tradición hispánica del grotesco:

Los autores españoles, juvenilmente endiosados, gustamos de salpicar con un poco de dolor la existencia que creamos. Tenemos áspera la paternidad. Por capricho y por fuerza. 
Luego, explica por qué los autores españoles se distancian de su obra al hacer hincapié en la función histórica de su espectáculo modernamente grotesco:

Porque nos asiste la indignación de lo que vemos ocurrir fatalmente a nuestros pies. España es un vasto escenario elegido por la tragedia. Siempre hay una hora dramática en España: un drama superior a las facultades de los intérpretes. Estos monigotes de cartón, sin idealidad y sin coraje, nos parecen ridículos en sus arreos de héroes. Gesticulan con torpeza de cómicos de la lengua las situaciones más sublimemente trágicas.

El análisis de Valle-Inclán muestra la conexión entre el efecto estético de la alienación de sus esperpentos y la necesidad de ver y rechazar, en la historia española, la ilusión de la tragedia como un desenmascaramiento asolador de las ideologías nacionales.

Esta es la razón por la cual vale exáminar de nuevo sus esperpentos, pero ahora modernísticamnte, en términos de los artistas conocidos de la modernidad que ofrecen válidas tendencias paralelas; al no ocultar el hecho de que el espectáculo grotesco de sus esperpentos ha sido artificiosamente construido, un público español no puede dejar de reflexionar críticamente, como puede suceder con los medios de comunicación, sobre las "situaciones trágicas" de España y sobre los modos de su representación en el arte y en la prensa. La moderna estética de ValleInclán refleja una creencia histórica que dice que una obra tradicional en la ficción o en la historia, debe ser rechazada para modernizarse. No puede irse más lejos respecto a la modernidad: exponer por medio de la estética que la historia, en su pretensión de ser históricamente auténtica, es fraudulenta. Como escritor moderno (más allá que Eliot, Pound, etc) Valle-Inclán supo renovar el aparato mismo de las historias.

De ahí la función moderna del experimentalismo de Valle-Inclán. La deformación grotesca de la historia, en ficción, está estructurada modernamente como una contradicción: 1) en el nivel esperpéntico del espectáculo, no se revela la identidad histórica, es decir, simbólica de los varios personajes y, al destacar en los diálogos y acotaciones modernizadas toda la gesticulación grotesca de marionetas, hace que cada esperpento represente un aspecto artificioso y por tanto aparente o falso de la realidad histórica de España; 2) a la vez, sin embargo, en el nivel referencial y por tanto simbólico de la "lectura" de las acotaciones escénicas y diálogos dramáticos (los dos productos del arte moderno), no se oculta nada sobre la dimensión histórica de los personajes fantochescos- españoles vistos en su afán de ser o no ser españoles. Al contrario, el público observa en todos sus detalles pertinentes todo lo que en el tablado de muñecos es histórico sobre la política, justicia, economía y corrupción; el tópico "encubrir" crímenes e injusticias se transforma en la muy extraña unión entre artificiosas grotesquerías artísticas y conocidas realidades históricas. Así que la fusión artística del grotesco moderno en el teatro de marionetas es, en la realidad de la lectura, la base de toda una estrategia de la modernidad: la solución del todo estética para unos problemas del todo históricos. 
